\title{
RUNCINA FERRUGINEA N.SP. (CEPHALASPIDEA: OPISTHOBRANCHIA: GASTROPODA), A NEW RUNCINID FROM GREAT BRITAIN
}

\author{
ANNETRUDI KRESS \\ Department of Anatomy, University of Basle, Switzerland
}

(Plates I-II, Figs. 1-4)

\begin{abstract}
A new species of the family Runcinidae is described. The name ferruginea reflects the fact that the animal displays a uniform reddish-brown colour.

The central tooth of the radula of $R$. ferruginea is bilobed and each lobe bears about ten slender denticles. The lateral teeth are hook-shaped and show smooth edges. The central tooth of Runcina coronata, the type species, is bilobed also, each lobe carrying only about five denticles but these being of a more prominent character. The lateral teeth have highly denticulated edges.

The male copulatory organ consists of three parts. A short penis protruding into an atrium, a prostate gland and a seminal vesicle.

The hermaphroditic and female part of the reproductive system consists of ovotestis, spermoviduct, spherical ampulla, fertilization chamber, uterus, albumen gland, mucous gland and a common genital duct leading to the exterior. From this duct a ciliated duct leads to the fertilization chamber. The organization of the reproductive system is basically the same as in $R$. coronata, the only differences are in the proportions of the different parts mentioned.
\end{abstract}

\section{INTRODUCTION}

Members of the small suborder Runcinacea have recently been reviewed and efforts have been made to group new findings (Burn, 1963; Baba, 1967; Miller \& Rudman, 1968). The following structures served for the classification: gills alone (Baba, 1967), gills, radula, gizzard-plates and shell (Burn, 1963). According to this classification a more detailed subdivision became necessary. Two proposals brought forward by Burn (1963) and Baba (1967) are in discussion (see below). Two new genera Runnica and Pseudoilbia (Miller \& Rudman, 1968) have not as yet been definitely placed in a family. As a consequence of this grouping some of the former members of the genus Runcina have been moved to another genus, e.g. Runcina elioti (Baba, 1937) to Runcinida (Burn, 1963) by reason of four or five gills surrounding the anus in a semi-circle, and Runcina setoensis (Baba, 1954; Ghiselin, 1963) to Metaruncina setoensis (Baba, 1967) because of its single gill and a greatly reduced radula (compare Table 1 ).

In the Plymouth Fauna List (Marine Biological Association, 1957) the only species of the Runcinacea found in that area to that date, is listed under the generic name Pelta. This name was supressed in 1967 (Lemche, Opinion No. 811) and Runcina again became the valid name. 
Two proposals towards the classification of the suborder Runcinacea:

Burn (1963)

FAM. ILDICIDAE

Genus: Ildica

FAM. RUNCINIDAE

Subfam. Runcininae

Genus : Runcina

Genus: Runcinida

Genus: Runcinella

Subfam. Ilbinae

Genus: Ilbia

(Not yet classified: Runnica, Pseudoilbia)
Baba (1967)

FAM. RUNCINIDAE

Genus: Ildica

Genus: Metaruncina

Genus: Runcina

Genus : Runcinida

Genus : Runcinella

Genus : $\overline{\text { Ilbia }}$

\section{MATERIAL}

Twenty animals of Runcina ferruginea n.sp. were first found between 21 and 30 August 1974 in a shallow sea-water tank in the Marine Biological Laboratory in Plymouth. The tank contained some rocks, a variety of algae and animals from the higher inter-tidal zone, and a great number of $R$. coronata. The specimens of $R$. ferruginea measured between $0.6-4 \mathrm{~mm}$ in length, being conspicuously different in colour and pattern from $R$. coronata.

In November $1975 \mathrm{I}$ received four animals measuring between 3.5 and $4 \mathrm{~mm}$ found in the same tank, as well as eggs, developing stages and hatching animals.

The species has not as yet been found outside the Laboratory, but they have lived there for more than 2 years and have been breeding. The external description is made from the holotype and the paratype. For the internal description two animals were used for the dissection of the radulae and gizzard plates; four animals for serial sections and reconstruction of the reproductive system. For comparison several $R$. coronata have been used in similar preparations.

\section{OBSERVATIONS}

Holotype: deposited in the Museum of Natural History in Basle, Switzerland, no. $11^{\prime} 105 a$; fixed and kept in formalin $5 \%$.

The living animal (Fig. 1) measured about $4 \mathrm{~mm}$ in length and about $1 \mathrm{~mm}$ in width at mid-length. The body is elongated, limaciform and has no tentacles. The mantel extends slightly beyond the foot except at the posterior end where the foot extends as a short tail, which protrudes during locomotion. The anterior edge of the foot is minutely notched in the median line. A quarter of the total length of the animal is taken up by the tail when the animal is well stretched. The tail tip is narrowly rounded. The mantle is smooth, broadly rounded behind and slightly wider towards the head. The head is shallowly bilobed in front. The eyes shine faintly through the skin.

The anus is situated behind the end of the mantle to the right of the median line. The renal pore opening is below the gills, just to the right of the anus (PI. ID). Three small gills more or less surround the anus and are just visible when the animal is crawling. The pinnate gills are about $235 \mu \mathrm{m}$ long when measured in serial section (P1. ID). There was no sign of an opaline gland.

The common genital aperture is located laterally to the gills. From there a narrow seminal groove runs towards the head. The anterior end of this groove meets the male aperture which opens to the right of the mouth. 
The colour of the body (dorsum, foot and gills) is a homogeneous reddish-brown and under the binocular the whole body seems to be powdered with very fine dark brown spots. The entire body is densely covered with cilia. No shell was found.

The movement of the animal were distinctly 'sluggish' compared with the very active $R$. coronata at the same time.

Paratype: deposited in the Museum for Natural History, Basle, Switzerland, no. $11,105 b$; fixed and kept in formalin $5 \%$.

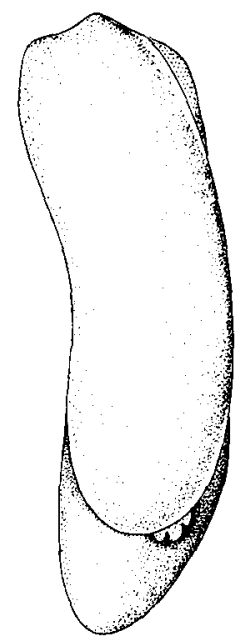

Fig. 1

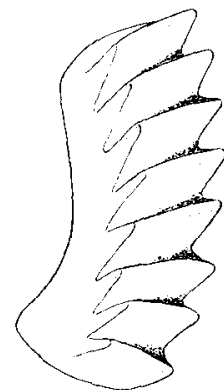

Fig. 2

Fig. 1. R. ferruginea. Drawing after a photograph from a living animal of $4 \mathrm{~mm}$.

Fig. 2. Gizzard plate (living animal $3.5 \mathrm{~mm}$ ). Length of the plate $180 \mu \mathrm{m}$.

The living animal measured about $3 \mathrm{~mm}$ in length and was approximately $0.8 \mathrm{~mm}$ broad. Colour and shape as well as the description of the animal are identical with that of the holotype.

Among the animals found were a great number of small ones. Slugs of $2.5 \mathrm{~mm}$ length were $0.6 \mathrm{~mm}$ broad, those of $1 \mathrm{~mm}$ length $0.3 \mathrm{~mm}$. The smaller the animals the lighter was the intensity of the brown colour. Animals of $1 \mathrm{~mm}$ length or less were very light brown, the foot was nearly colourless with only a very slight tinge of reddish-brown. In animals smaller than about $2 \mathrm{~mm}$ the digestive gland shows through the skin as an oval, dark brown complex within the posterior part of the notum.

Eggs: these measured between $400-440 \mu \mathrm{m}$ including all the capsule layers. Each egg had a diameter of $320-350 \mu \mathrm{m}$. There was one egg per capsule and during development no veliger stage could be observed. Newly hatched animals measured $0.6 \mathrm{~mm}$ in length and $0.2 \mathrm{~mm}$ in width.

There were too many temperature changes during development to allow any definite statement to be made regarding the normal duration of this period.

The reproductive system, the gizzard plates, radula and jaws are described according to the findings from preparations and serial section of six animals.

The jaws are composed of minute pointed denticles triangular in shape (P1. IA) and 
measuring $2-3 \mu \mathrm{m}$ at the base, $4-5 \mu \mathrm{m}$ in height. The radula formula is 1.1.1. An animal which measured $3.5 \mathrm{~mm}$ alive had 25 rows of teeth. The oldest of the rhachidians is $12 \mu \mathrm{m}$ broad and $8 \mu \mathrm{m}$ high at the highest point (Pl. IC). It is bilobed, each lobe carrying about ten slender denticles $1 \mu \mathrm{m}$ high and $0.2 \mu \mathrm{m}$ wide. On each side of the rhachidian are the hook shaped lateral teeth with smooth edges. These teeth are $22.5 \mu \mathrm{m}$ broad and $13.5 \mu \mathrm{m}$ high (Pl. IE).

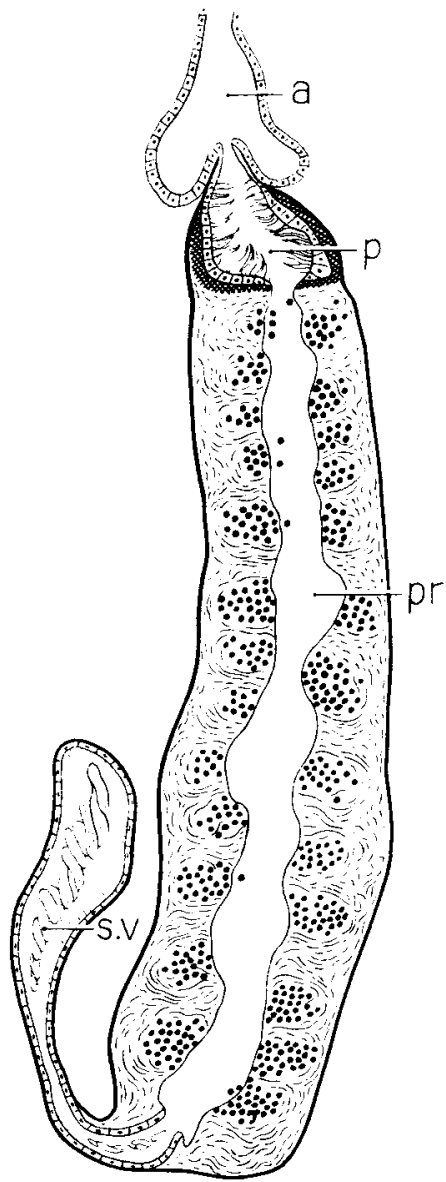

Fig. 3

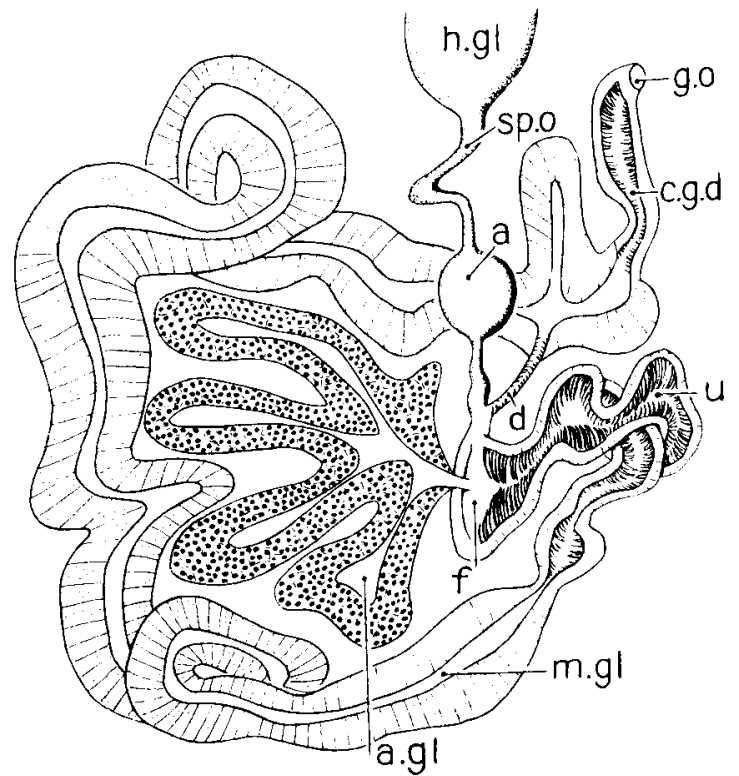

Fig. 4

Fig. 3. Male copulatory organ (proportions correct). $\mathrm{a}=$ atrium, $\mathrm{p}=$ penis, $\mathrm{pr}=$ prostate gland, sv $=$ seminal vesicle containing sperm.

Fig. 4. Female parts of the reproductive system (simplified, proportions only approximately): $\mathrm{a}=$ ampulla, a. gl. $=$ albumen gland, c.g.d. $=$ common genital duct, $\mathrm{d}=$ duct covered with cilia, $\mathbf{f}=$ fertilization chamber, g.o $=$ genital opening, $\mathrm{h} . \mathrm{gl}=$ hermaphroditic gland, $\mathrm{m} . \mathrm{gl}=$ mucous gland, sp.o $=$ spermoviduct, $\mathrm{u}=$ uterus.

There were four gizzard plates slightly curved and armed with eight deeply folded transverse laminae which show a straight edge (Fig. 2). One plate measures about $170-180 \mu \mathrm{m}$ in length, $80 \mu \mathrm{m}$ in height and is $80 \mu \mathrm{m}$ wide.

The male copulatory organ (Fig. 3) extends from the anterior male orifice which opens 
to the right of the mouth, backwards partly underneath the stomach and the hermaphroditic gland. In an animal of about $4 \mathrm{~mm}$ the organ comprises an atrium about $120 \mu \mathrm{m}$ long with an exterior diameter of $110 \mu \mathrm{m}$ and a constricted aperture. A short broad penis projects into the atrium (Pl. IIF), about $120 \mu \mathrm{m}$ long, with a diameter of $150 \mu \mathrm{m}$ The wall is covered with a columnar epithelium bearing long cilia. There is a sphincter muscle between the penis and the adjoining prostate gland. The prostate gland itself is a long cylindrical organ, the length being about $940 \mu \mathrm{m}$ and its diameter varying between 165 and $200 \mu \mathrm{m}$, it has glandular walls and a narrow lumen (PI. IIE). The other end of the prostate opens into an oval shaped seminal vesicle of about $420 \mu \mathrm{m}$ length and $65 \times 50 \mu \mathrm{m}$ in diameter. The wall consists of a regular cubical epithelium with short cilia. The organ is usually densely packed with sperm (Pl. IIE).

Complete understanding of the female reproductive organ (Fig. 4) is difficult. Most of the ducts are very thin but must be capable of considerable expansion in view of the great size of the eggs, few in number as they are.

The hermaphroditic gland is placed dorsally in front, to the right side and behind the digestive gland. The sperm matures centrally, the eggs (PI. IIG) are arranged more peripherally. From the posterior end of the hermaphroditic gland a spermoviduct runs to a spherical ampulla (Pl. IIc). From this ampulla a twisting duct, occasionally with some dilatations leads to a chamber with an irregular outline, the fertilization chamber. A ciliated duct enters this chamber. This duct forks off from the mucous gland near the common genital opening. The albumen gland (P1. IID) opens into this fertilization chamber as well. The fertilization chamber itself leads into a ciliated chamber (Baba, 1967) or so-called uterus (Colosi, 1915). The cilia here are densely packed and very long. This uterus leads into the mucous gland (PI. IID) which is heavily folded. The mucous gland ends in the common genital duct which penetrates obliquely through the body wall to the exterior (PI. IIC). There is no bursa copulatrix.

\section{DISCUSSION}

From the point of view of coloration all the species of the genus Runcina are quite distinct (Table 2). From the description of the hue as well as the radula, the gills and other items, Pruvot-Fol (1954) seems right in saying that $R$. calaritana (Colosi, 1915) is a synonym for $R$. coronata. Her view that $R$. capreensis (Mazzarelli, 1894) is identical with $R$. coronata is wrong because of the distinct pattern of big black dots as well as the size of the gills and the shape of the radula. $R$. coronata, $R$. marshae as well as $R$. ferruginea have gills which extend beyond the mantle, especially when the animal is moving. $R$. capreensis and $R$. australis have very small rudimentary gills while $R$. prasina exhibits only one gill in a lateral position, which makes its place among the Runcina somewhat doubtful.

The character of the epithelium on the under side of the mantle above the gills showed no signs of specialization in $R$. ferruginea, while in $R$. coronata the epithelial mucous glands seem to be absent (Pl. IIA).

In all species with jaws these are described as small elements more or less square or triangular in shape. In serial sections through $R$. ferruginea and $R$. coronata both shapes 
could be found probably due to the amount of abrasion and plane of section. With the exception of $R$. africana and $R$. capreensis all the members of the genus Runcina display a bilobed rhachidian and except for $R$. australis bear a varying number of denticles. In $R$. ferruginea the number of these denticles differs from that of other species. The lateral teeth in $R$. ferruginea are hook-shaped, the edges smooth as in $R$. africana, $R$. marshae and $R$. capreensis (Table 2). The type species $R$. coronata exhibits a dense row of denticles (Pl. IF). The gizzard plates vary in shape, and in the number of ridges or denticles (Table 2). Compared with the type species $R$. coronata which in our case had 10-11 ridges on each plate (Pl. IB), $R$. ferruginea has only about eight and has smaller and straight ridges. Burn (1963) postulated a difference between $R$. coronata from the Mediterranean and the Atlantic because Alder \& Hancock (1846) drew only six laminae on each gizzard plate. According to my findings this is due only to the size of the animal.

No shell has been seen, either in $R$. coronata or in $R$. ferruginea. Vayssière $(1883,1885)$ believes that he saw a reduced one in certain animals.

The opaline or anal gland does not appear as a constant structure within the Runcinacea. In Runcinella (Odhner, 1924) it is well developed and consists of a sac opening beneath the anus and containing seven date-like corpuscles, each of them of glandular formation. In Metaruncina a number of compound glandules open to the exterior above and slightly to the left of the anus. With the exception of $R$. coronata no opaline gland is mentioned in any of the member of the genus Runcina and none has been found in $R$. ferruginea. In $R$. coronata this gland lies above the anus (Colosi, 1915) and opens through a short duct above and somewhat to the left of it (Pl. IIB). The gland measures about $125 \times 80 \mu \mathrm{m}$ in diameter and consists of a small number of large cells with an extremely basal lying cell nucleus. The contents of the cells seems to be destroyed by the fixative, and they appear empty (Pl. II A, B).

As far as the other genera such as Runnica and Pseudoilbia are concerned it is not yet certain if such a gland exists. For Ilbia ilbi (Burn, 1963) an opaline gland is noted, but Burn himself corrected his observations in 1969 stating that this interpretation was wrong and that no gland could be found (Table 1).

In $R$. ferruginea we have a direct development without veliger stage as already described for $R$. coronata (Vayssière, 1900) and Metaruncina setoensis (Baba \& Hamatani, 1959).

In the suborder Runcinacea the male copulatory organs are separated from the rest of the reproductive system and lie independently in the right anterior and ventral part of the body. The opening is found to the right of the mouth. In three of the four species of Runcina described ( $R$. coronata, $R$. capreensis, $R$. australis and $R$. ferruginea) the copulatory organs consist of the three parts: a penis, prostate gland, and a seminal vesicle to store the sperm. The penis is muscular and protrudes into an atrium with a constructed opening. The penis is shorter in $R$. ferruginea than in $R$. coronata, not only in absolute figures, which vary with the size of the animal but in relation to the total length of the penis, prostate gland and seminal vesicle. The length of the penis in $R$. ferruginea is about $8 \%$, in $R$. coronata about $11 \%$ of the total length of the copulatory organ.

The prostate gland is long and cylindrical in shape in $R$. coronata and also $R$. ferruginea, but in $R$. australis is shorter and fusiform. No sphincter muscle is found in this species between the prostate and the penis but a narrow coiled penial duct is inserted between 
these two organs. The seminal vesicle or bulbus seminalis (Ghiselin, 1963; Baba, 1967) is considerably shorter than the prostate in mature animals of $R$. coronata and $R$. ferruginea, but is about the same length as the prostate in $R$. australis.

The ciliated groove running from the genital opening to the male orifice shows no further specialization. This perhaps accounts for the fact that Mazzarelli (1894) describes no groove in $R$. capreensis, in spite of the identical arrangement of the genital organs to those of other runcinids. Colosi (1915) thinks that the seminal vesicle is filled with allosperm and that this is transported through the seminal groove to the genital opening for fertilization of the eggs. Today it is known that the autosperm travels through the seminal groove and is stored in the seminal vesicle. In Ildica, Runcinella and Runcinida it is difficult to understand how the transfer of sperm can occur during copulation when no seminal vesicle exists (Ghiselin, 1963).

The female part of the genital system is not very well known in the Runcinacea as Table 1 demonstrates and therefore these criteria have not been used for classification. That many facts are still unknown is due partly to the lack of a sufficient number of animals for description and partly because the specimens in question had not reached sexual maturity. Most authors only checked if a bursa copulatrix exists (Burn, 1963 Miller \& Rudman, 1968). Vayssière (1883) describes a 'poche copulatrice' for $R$. coronata which in our serial sections cannot be found.

The most detailed drawing has been published by Baba (1967) for Metaruncina setoensis. The principle of the organization seems basically the same as in $R$. ferruginea and $R$. coronata. Colosi (1915) gives a complicated account of the genital system of $R$. calaritana $(=R$. coronata). In his description and his drawing however no duct is apparent to allow the heterosperm to reach the fertilization chamber. He concludes that they pass through the whole female gland mass.

The nomenclature for the different parts of the female gland mass is contradictory. So it would seem that the term 'uterus' is used in different ways by Odhner (1924) in Runcinella, and by Colosi (1915) in R. calaritana and is called 'ciliated chamber' by Baba (1967) in Metaruncina.

$R$. ferruginea has a longer and more twisted hermaphroditic duct than $R$. coronata. The common duct leading to the exterior is rather short in $R$. ferruginea but forms a long loop within the body wall in $R$. coronata.

Tables 1 and 2 demonstrate the great difficulties met with in classifying this small group of Runcinacea. Each genus differs in one or two items only and consists generally of only one species.

What is known about $R$. prasina (Mörch, 1863) and $R$. inconspicua (Verrill, 1901-3) makes it doubtful if their grouping within the genus Runcina is correct. The same applies in the case of $R$. australis, the only species which exhibits a bursa copulatrix and a penial coil.

According to the radula, gills, gizzard plates and genital system the newly described $R$. ferruginea, however, can be placed in this genus together with the type species R. coronata. 
密害总

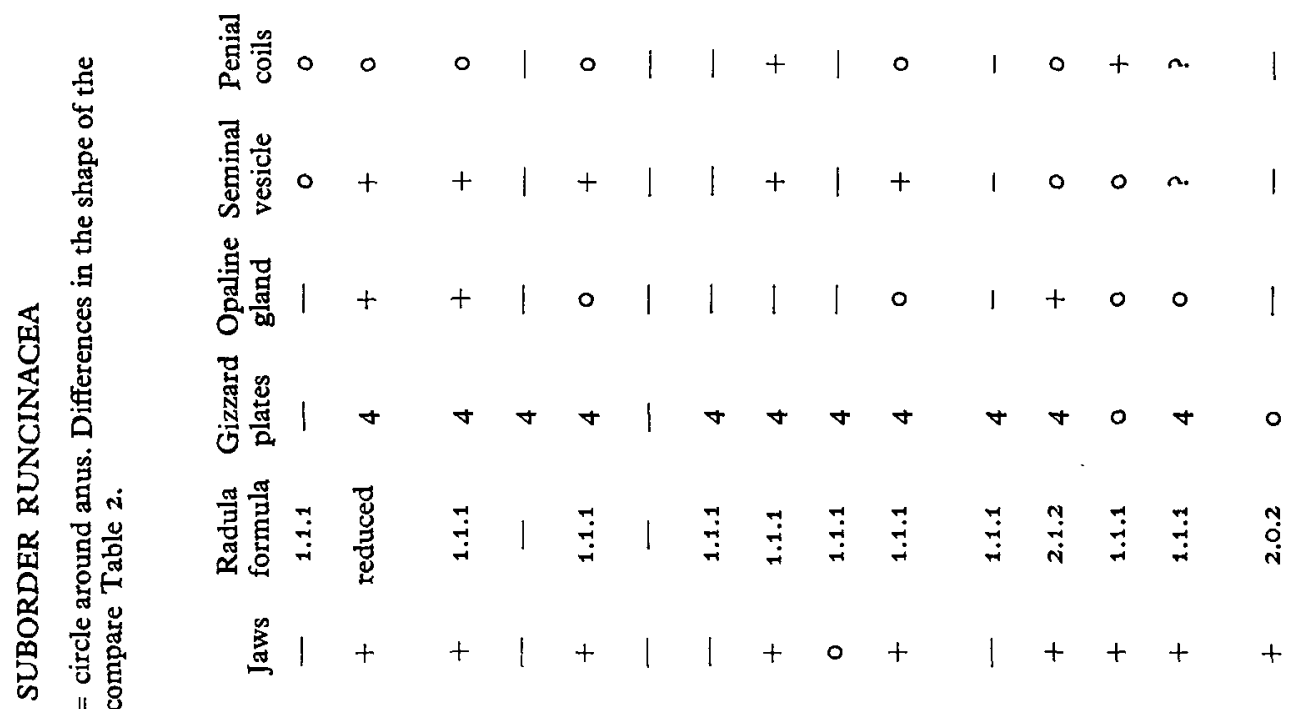

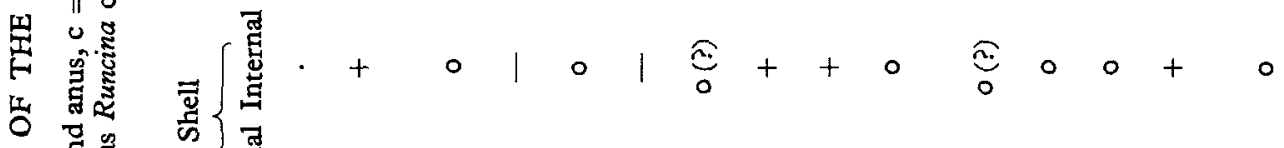

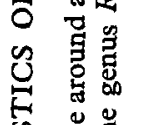

药

舫

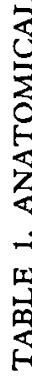

芯焉焉

武莒

空

$\int_{\substack{r \\ r}}^{n} \cdot$

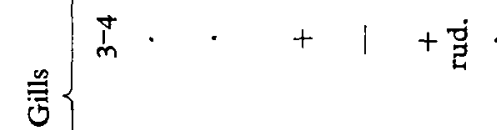

0

$+++\cdot+\approx 1$

$\circ$.

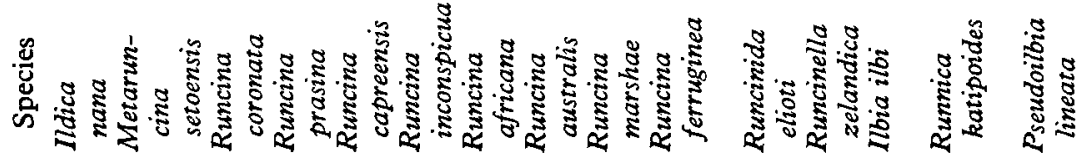

Downloaded from https:/www.cambridge.org/core. University of Basel Library, on 11 Jul 2017 at 09:10:53, subject to the Cambridge Core terms of use, 


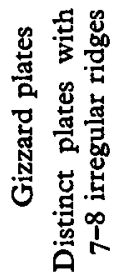

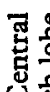
Uす⿺辶寸

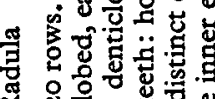

$\sum_{\substack{2 \\ 3}}^{3}$

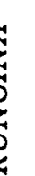

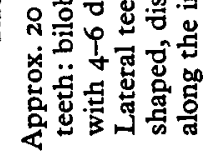

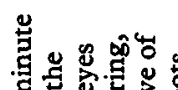

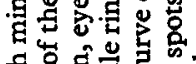

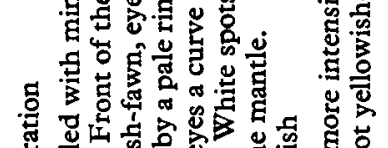

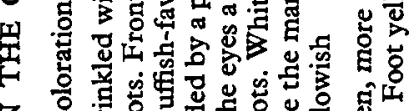

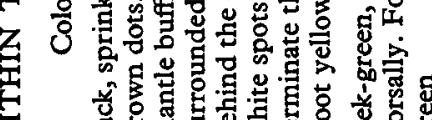

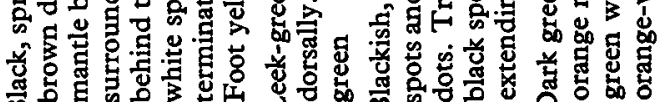

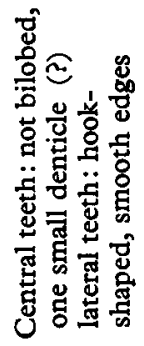

要

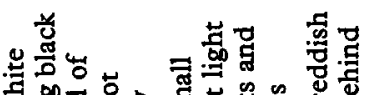

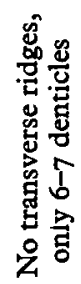

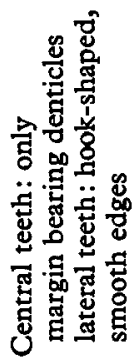

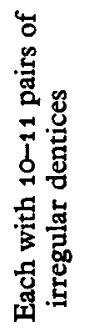

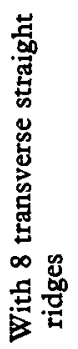
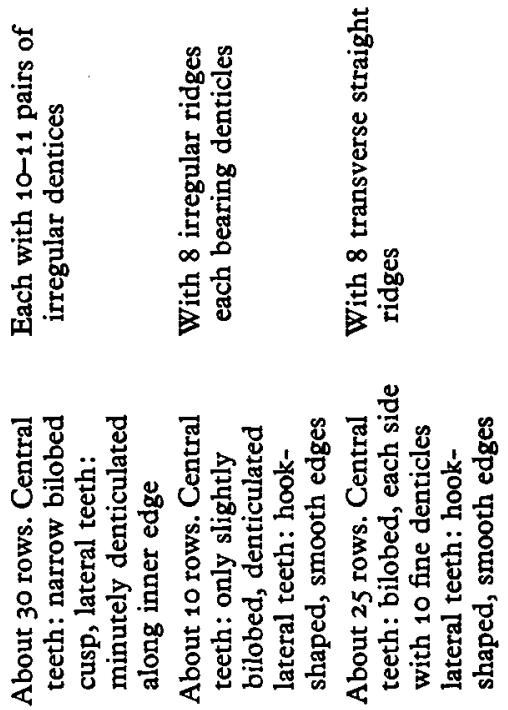

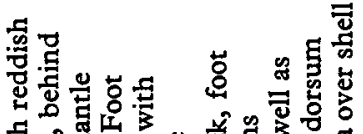

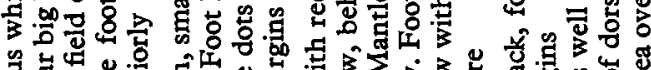

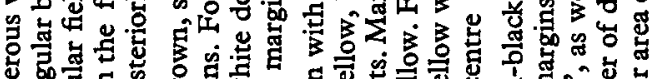

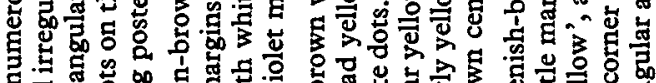

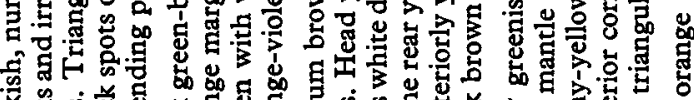

告

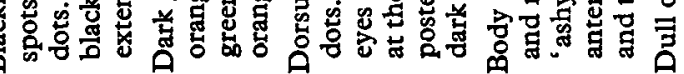


I wish to thank the Director of the Plymouth Laboratory, for providing facilities during summer 1974, John Green from the Specimen Department for helping me to collect the specimens and for sending me animals, eggs and developing stages in November 1975. I am grateful to Miss L. Serpell for her help with the English manuscript and Mrs Schaller and Mrs Zmorsky for their assistance with the serial section as well as Miss Brücher (Ciba-Geigy, Basle) for the scanning electron microscope pictures.

\section{ADDENDUM}

A visit to Plymouth after submission of this paper for publication, gave me an opportunity to examine a specimen which had been dredged from Duke Rock (Plymouth Sound) on 12 April 1976. Two members of the Specimen Department examined the living specimen and came to the conclusion that the appearance was identical with that of $R$. ferruginea found in the tank and described above. My subsequent preparations of the radula (S.E.M.) and of the gizzard plates confirmed this identification. We therefore now have the first record for the Plymouth area outside the Laboratory itself.

It is interesting to note the difference in habitat between $R$. coronata, which has been recorded only from intertidal rock pools, and this specimen of $R$. ferruginea which was dredged from a depth of about $10 \mathrm{~m}$.

Since the time that $R$. ferruginea was first recorded from the tank in the Laboratory there has been a remarkable proliferation of the species there, and specimens can now be observed of a size up to $8 \mathrm{~mm}$ in length and $2 \mathrm{~mm}$ in width.

Eggs have been laid in the tank during the months of August and September.

Another observation of interest is that specimens there are frequently found to swim at the water surface, a behaviour never seen in $R$. coronata in the same tank.

\section{REFERENCES}

Alder, J. \& Hancock, A., 1846. Notices of some new and rare British species of naked Mollusca. Annals and Magazine of Natural History, 18, 289-294.

BABA, K., 1937. Opisthobranchia of Japan. I. Fournal of the Department of Agriculture, Kyûshû Imperial University, 5, 195-235.

BABA, K., 1954. Runcina setoensis, a new and rare species from the coast KII, Middle Japan (Opisthobranchia). Publications of the Seto Marine Biological Laboratory, 3, 373-374.

BABA, K., 1967. Supplementary notes on the anatomy of Metaruncina setoensis (Baba, 1954), (N.G.) (Opisthobranchia-Cephalaspidea). Publications of the Seto Marine Biological Laboratory, 15, 185-197.

Baba, K. \& Hamatani, I., 1959. The direct development in Runcina setoensis Baba (Opisthobranchia-Cephalaspidea). Publications of the Seto Marine Biological Laboratory, 7, 281-290.

BERgH, R., 1889. Malacologische Untersuchungen. In Reisen im Archipel der Philippinen, bd. II (in 3 vols), (ed. C. Semper), pp. 815-872.

BuRN, R., 1963. Australian Runcinacea (Mollusca: Gastropoda). Australian Zoologist, 13, 9-22.

BURN, R., 1966. The opisthobranchs of a Caulerpan microfauna from Fiji. Proceedings of the Malacological Society of London, 37, 45-65.

BURN, R., 1969. A memorial report on the Tom Crawford collection of Victorian Opisthobranchia. Fournal of the Malacological Society of Australia, 12, 64-106.

Colosi, G., 1915. Osservazioni anatomo-istologiche sulla Runcina calaritana n.sp. Memorie della $R$. Accademia delle Scienze di Torino, Ser. II, 66 (6), 1-35.

Forbes, E. \& Hanley, S., 1851. A History of British Mollusca and Their Shells, vol. 3. 616 pp. London: Van Voorst.

GHISELIN, T., 1963. On the functional and comparative anatomy of Runcina setoensis Baba, an opisthobranch gastropod. Publications of the Seto Marine Biological Laboratory, 11, 389-398. 

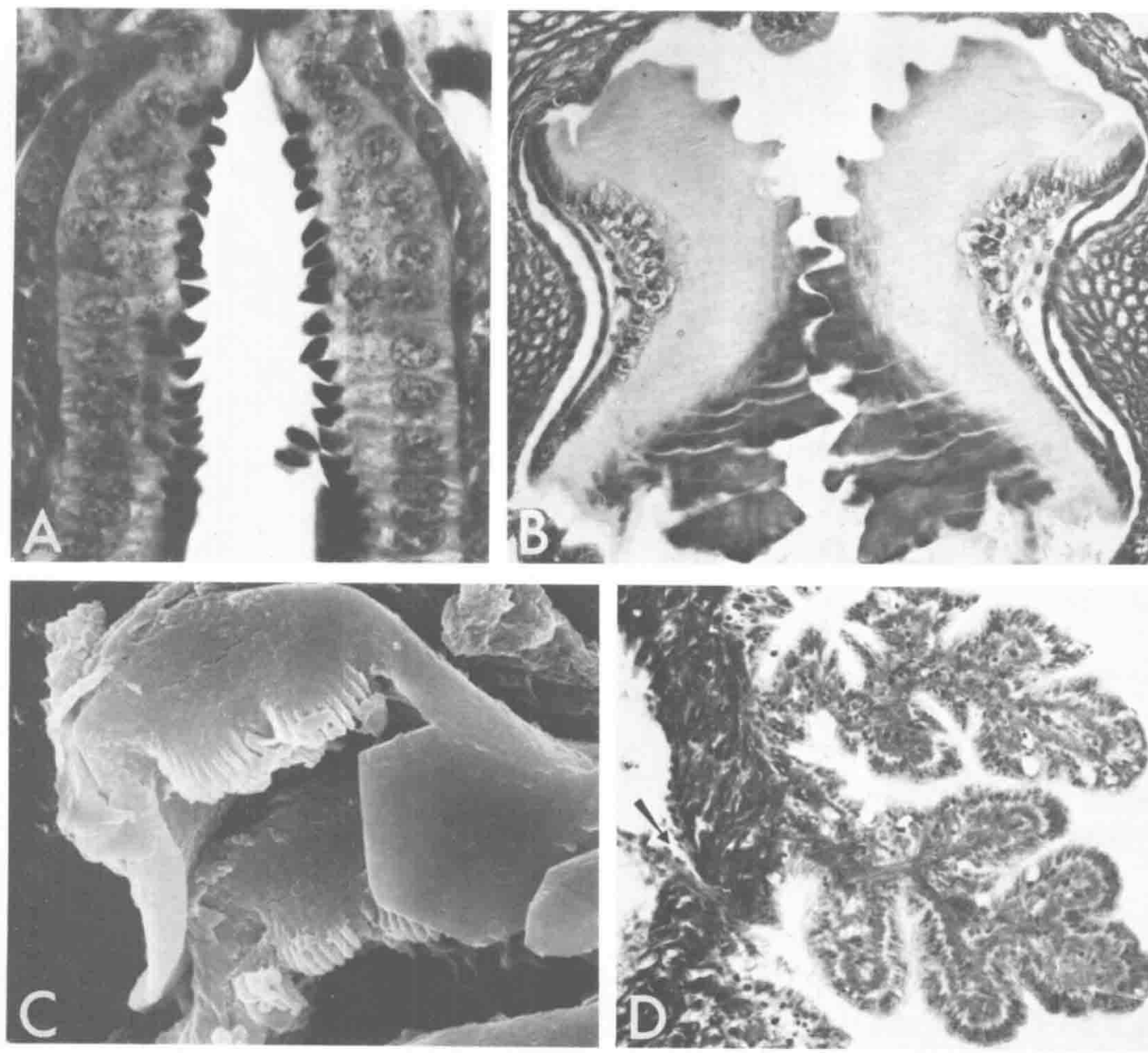

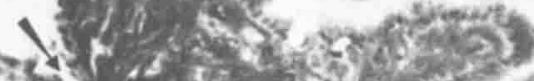

Th. $y^{2}$;

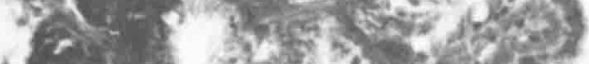

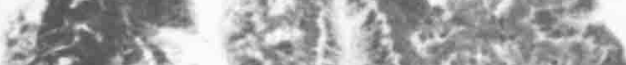

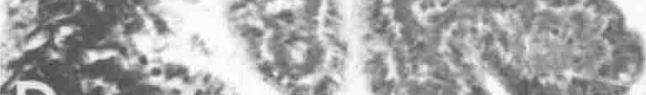

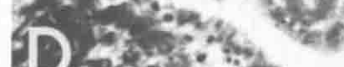
D.
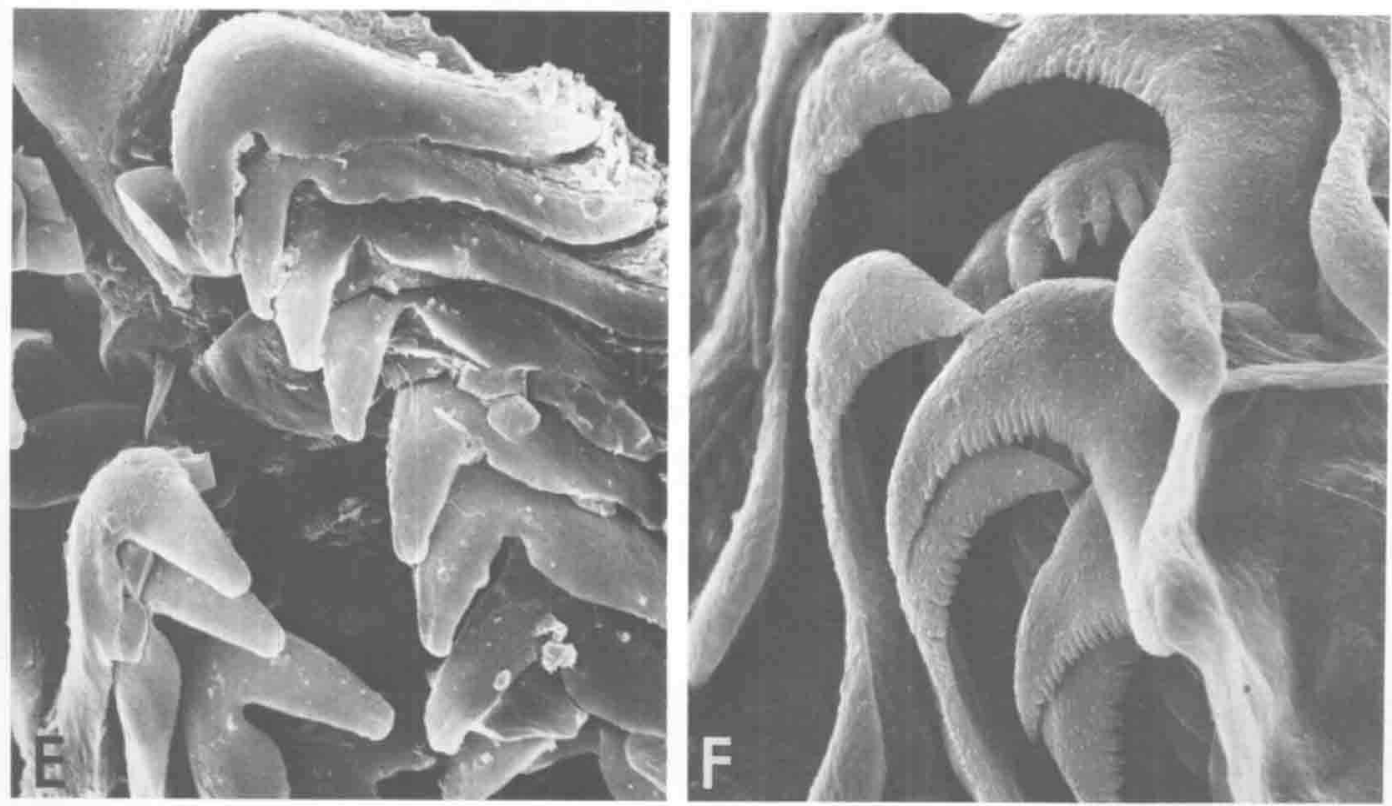

(Facing p. 210) 

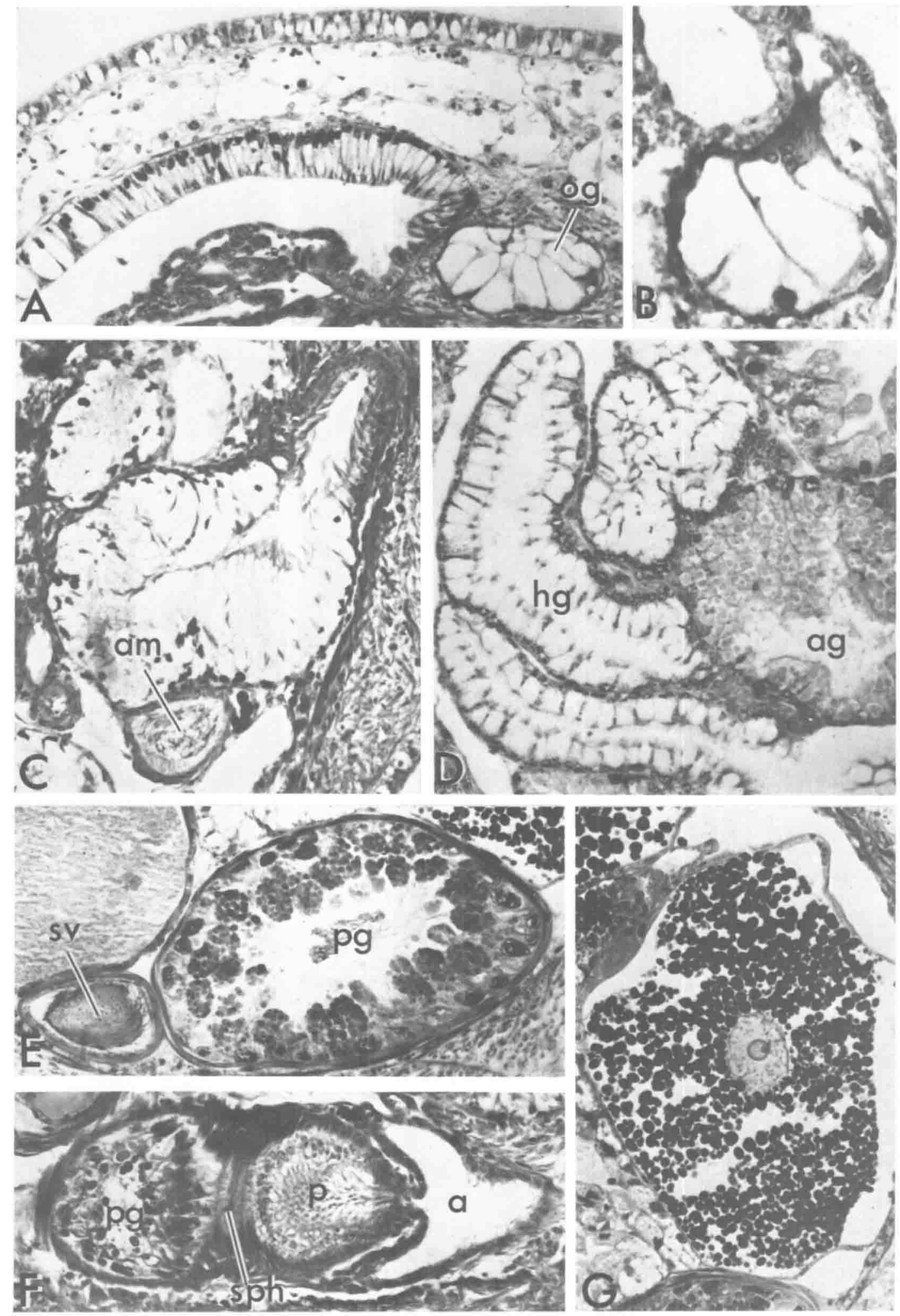
Lemche, H., 1965. Pelta Quatrefages, 1844, or Runcina Forbes 1851 (Gastropoda): two competing names for a place on the official list. Z.N. (S.) 580 . Bulletin of Zoological Nomenclature, 22, 49-50.

LEMCHE, H., 1967. Runcina Forbes, 1851 (Gastropoda): validated under the plenary powers. Opinion 811. Bulletin of Zoological Nomenclature, 24, 89-90.

Marine Biological Association, 1957. Plymouth Marine Fauna, 3rd ed. xliii, 457 pp. Plymouth.

Mazzarelli, G., 1894. Ricerche sulle Peltidae del Golfo di Napoli. Atti della R. Accademia delle Scienze fisiche e matematiche Napoli, Ser. 2, 6 (4), 1-18.

Miller, M. \& RUDMAN, W., 1968. Two new genera and species of the superfamily Runcinoidea (Mollusca Gastropoda: Opisthobranchia) from New Zealand. Transactions of the Royal Society of New Zealand, 10, 183-189.

Mörch, M., 1863. Contributions à la Faune malacologique des Antilles danoises. Fournal de conchyliologie, Ser. $3,11,21-43$.

Odhner, N., 1924. Papers from Dr Th. Mortensen Pacific Expedition 1914-16. New Zealand Mollusca. Videnskabelige Meddelelser fra Dansk naturhistorisk Forening $i$ Kjobenhavn, 77, $1-90$.

Pruvot-Fol, A., 1953. Etude de quelques opisthobranches de la côte atlantique du Maroc et du Sénégal. Travaux de l'Institut scientifique chérifien (Zoologie), 5, 1-105.

Pruvot-Fol, A., 1954. Mollusques Opisthobranches. Faune de France, No. 58, 460 pp.

Quatrefages DE, J., 1844. Mémoire sur les Gastéropodes phlébentérés, ordre nouveau de la classe des gastéropodes. Annales des sciences naturelles (Zoologie), Sér. 3, 1, 129-183.

Vayssière, A., 1883. Les genres Pelta (Runcina) et Tylodina. Annales des sciences naturelles (Zoologie), Ser. 6, 15, 1-46.

VAYSSIÈRE, A., 1885. Recherches zoologiques et anatomiques sur les Opisthobranches du Golfe de Marseille I. Annales du Musée d'histoire naturelle de Marseille (Zoologie), 2, 1-180.

VAYssière, A., 1900. Note sur un nouveau cas de condensation embryogénique observé chez le Pelta coronata, type de Tectibranche. Zoologischer Anzeiger, 23, 286-288.

Verrill, A., 1901-3. Additions to the fauna of the Bermudas. Transactions of the Connecticut Academy of Arts and Sciences, 11, 15-62.

\section{EXPLANATION OF PLATES}

\section{Plate I}

A. $R$. ferruginea: jaw, triangular elements, $\times 1200$.

B. $R$. coronata: gizzard plates, $\times 200$.

C. R. ferruginea : radula, central tooth, bilobed, each lobe with 10 denticles, scanning electron microscope. $\times 5000$.

D. R. ferruginea: longitudinal section through two gills. Renal pore opening below the gills (arrow) $\times 200$.

E. $R$. ferruginea: radula, lateral teeth with smooth edges, scanning electron microscope. $\times 2000$.

F. $R$. coronata: radula, lateral teeth with distinct denticles, scanning electron microscope. $\times 1200$.

\section{Plate II}

A. $R$. coronata: sagittal section through the opaline gland $(\mathrm{og})$ and gills, showing the different aspect of the epithelium above the gills. $\times 200$.

B. $R$. coronata: opaline gland with duct leading to the exterior. $\times 380$.

c. $R$. ferruginea: parts of the mucous gland leading into the strongly ciliated common genital duct. am = ampulla, $\times 250$.

D. $R$. ferruginea: part of the albumen gland (ag) and the mucous gland (hg). $\times 250$.

E. $R$. ferruginea: section through prostate gland (pg) and seminal vesicle (sv) $\times 250$.

F. R. ferruginea: section through atrium (a), penis (p) and prostate gland (pg). Sphincter muscle between penis and prostate gland $(\mathrm{sph}) . \times 250$.

G. $R$. ferruginea: nearly mature egg, $\times 250$. 